\title{
Power and force: Rethinking Kojève, Arendt and Camus in the populist era
}

\author{
Maciej KAŁUŻA*
}

\begin{abstract}
In the presented essay, I would like to focus on the relationship between force and power. The idea that power, without resorting to forceful, even violent solutions, is less problematic, is both deceitful and dangerous. Once accepted, it can cause an oversight of violence-free but possibly harmful forms of power. My focus in the article will be on the two reinterpretations of Master-Slave dialectics, as presented by Alexandre Kojève and Albert Camus. This will be presented with reference to the position of Hannah Arendt and her remarks on power and force. In conclusion, I will be abstemious: my goal is rather to diagnose and bind the existentialist judgement with the contemporary situation and suggest that thinking outside the force-power relationship may be continuously fruitful and an important part of reflection on the nature of political power.
\end{abstract}

\section{KEYWORDS}

Master-Slave dialectic; violence and power; populism; domination

* Ph.D., assistant professor at Department of Philosophy and Sociology, Pedagogical University of Cracow, Poland. E-mail: maciej.kaluza@up.krakow.pl. 


\section{INTRODUCTION}

In her seminal work, On violence, Hannah Arendt tried to distinguish and define the concepts of violence, power, strength and power. Curiously, she did very little to explain the role of force (Arendt, 1970: 44-46); her main focus remained on establishing the significance of the relationship between strength and violence, before concluding with her notable analysis of political power being restrained from the use of violence. In contrast, a recent influential study of political violence by Tony Coady (Coady, 2007), in consensus with John Dewey's argument (Dewey, 1916: 296-296), stresses the importance of understanding violence by means of application of force, while underplaying the concept of strength. In these analyses, violence is seen as a destructive and harmful application of force. Additionally, it seems that there is a tendency in recent scholarship to see violence predominantly in the normative sphere as both a wrong and a bad use of force (Bufacchi, 2007). The study of this relationship, between violence and force has abundant scholarship, which is predominantly interested in a normative evaluation of the wrongness of violence, which is defined as a direct or indirect, intentional or non-intentional, physical or psychological exercise of force. The point of this essay is to focus on Arendt's question regarding the legitimacy of power in relation to the issue of using force as a means of achieving a state of control over others. In the first part of this essay, I will relate to the origin of power, as interpreted by Alexandre Kojève (Kojève, 1980) based on Georg Wilhelm Friedrich Hegel's writings. In the second part of the work, I will challenge the necessity of the relationship between using force and achieving power. However, contrary to Arendt, I will try to demonstrate how power can be achieved without the use of force, without being openly violent, for the sole purpose of domination. In conclusion, I will suggest that the care taken in limiting power resulting from force, although just and understandable, should be accompanied by an equally intensive caution towards contemporary populist strategies of reaching political power, dressed as non-violent, force-free and achievable by democratic means.

\section{PART 1: POWER OF THE STRONG: FORCE AND DOMINATION}

In his famous analysis of Hegel's Phenomenology of the mind, Kojève proposed an analysis of force (Kojève, 1980) as the originating source for political power. I believe it is important to start with the analysis of Master-Slave dialectics, because it offers several important conditions for our understanding of force (and consequently, our understanding of violence) in their relation to political power. From this source, we can learn that: 
1. The parties of the power struggle are socially equal and have at least, potentially, an equal chance in the conflict.

2. There is no mention in Hegel, nor Kojève, whatsoever of the disproportion of force between the subjects. Both assume, that they can win the fight.

3. Both parties are aware that it is only by use of force that they can achieve success and exert power upon the other. No peaceful solution is offered here as an alternative resolution to the conflict.

4. Both parties are aware that some limitation of force must be accomplished for the benefit of their goals. The destruction of the opponent is counter effective from the standpoint of the necessity of the agent to be recognized as a Master.

The fourth point is especially significant in Kojève's analysis, and highly important for us: the conversion of force to violence, the destruction of the second party (here understood as violence) results in the impossibility of being recognized by the loser of the struggle as the victorious party. Thus, the subject who is winning, the Master, needs recognition of his victory. In the analyzed example, the relationship between power, force and violence stands on knowledge and recognition. By preserving the limit between force (used to defeat the opponent) and violence (destruction of the opponent) in the confrontation, one gains access to knowledge of himself (in the Mastery, initiating the power relation with the other). The second side also paradoxically gains something: he gains knowledge of his own inferiority, leading to the change of existential strategy for survival (recognition of mastery in another Master and one's dependency on his will).

So, according to Kojève, the Master decides to preserve the Slave for his own benefit: to obtain recognition; to fulfill the desire to be desired, even if this desire comes from a "lesser" being, the Slave, who is not an equal. Both sides of the conflict are not satisfied. The Master gains recognition, but only by the Slave, who was defeated in the initial conflict. To preserve the status of being the Master, constant humiliation of the Slave is performed by the ruling party, while it is still necessary for the Master to avoid the use of a completely destructive, violent force.

Jon Elster (Elster, 1984) maintains that there is an intriguing, normative aspect to the desire to be desired. It is because of the enforced gratitude of the Slave that the Master considers himself a moral being, even though he must humiliate the Slave and solidify his status with the threat of being violent. His primary concern, in this reading, is his moral and not his political status. Peter Stallybrass and Allon White (Stallybrass \& White, 1986: 191) offer a different explanation, which I believe will be useful for our analysis. Rather than emphasizing the realm of morality, they claim that the Master wants to identify with power. He humiliates the Slave, to assure himself as to his own 
power and superiority. ${ }^{1}$ In this reinterpretation, the Master needs the Slave, and he needs the Slave to be humiliated, because this offers him knowledge about his own relation to power, without the need to repeat the dangerous part of the confrontation with the other, where the risk of losing is much more considerable.

The restriction of force, so that it does not become violence during the struggle, leads to permanent use of violence by the Master in his attempt to maintain power. This violence, while not completely destructive, is clearly detrimental for the Slave. It becomes a form of exploitation, in which no physical, forceful activity is necessary to induce harm and suffering in the victim. In the initial struggle, the Slave yielded to force, but was spared violence. In the social relationship after the first struggle, the Slave is a victim of violence, but not necessarily of force: the Master does not have to physically abuse the Slave, he restricts himself from killing the Slave, as that would lead to apprehension of his own status as a Master. However, he must be violent in a different way: he must enforce the constant confirmation of his status as a Master on the Slave's consciousness: through both repetitive humiliation and the destruction of the desire in the Slave to become someone else. Permanent social violence is born out of an original limitation of force. A force, which was primarily empirical and restricted, becomes the source of humiliation. Violence, which was primarily avoided, becomes permanent in the form of exploitation and humiliation.

So far, we have only discussed the conversion from force to violence, with the effect of force becoming purely dispositional, and violence, in the form of humiliation, becoming the basis for social, structural and political elements of power. It is well known that Kojève's analysis also considered the possibilities for the Slave to reverse and change his social situation. Clearly inspired by the Marxist analysis of the evolution of the Slave in Kojève, it was argued that in order to reverse the violent conditions of exploitation, force must be used by the subordinated, in order to regain their equal status and apprehend the ontological status of the Masters. Even though the force, as used by the Master in the initial struggle, was limited so as to avoid the destruction of the opponent, the question for many influential works in social philosophy relates to the nature of the activity that should reverse the situation.

This debate had very serious ethical and political consequences, as many believed that the re-establishment of the dignified status of the victimized subject must be performed through violence, which is unequivocally understood as the destructive application of force. To redefine oneself as the power-wielding

\footnotetext{
${ }^{1}$ Outside the analysis of Master-Slave dialectics, Bufacchi also confirms the relationship between humiliation and power: "In the act of causing humiliation, a person is using another person to establish or reinforce their identity with power" (Bufacchi, 2007: 157).
} 
subject, the Master had to humiliate. As he was not chosen to wield power, the status of his power was determined by his own ability to make others believe that the origin of power itself comes from force. This interpretation, when applied to history, has consequences when thinking about the social situation of genuinely humiliated people and can be perfectly seen in the debate about colonialism in the 1950's. According to some influential political theorists, in order to redefine himself once more as no longer being a Slave, the subordinated must destroy the Master (Sartre, 1961). It is only by means of violence and not force, conditioned by some more or less severe limitations, that one can regain one's status as a free person, after suffering the humiliating conditions and exploitation by the Master.

Jean-Paul Sartre considers the reversal of the situation of the humiliated only to be achievable by means of symmetrical reversal: the reappearance of the dignity of the former Slave must be achieved by destruction: a physical elimination of the former Masters. In his opinion, the result is freedom, and he does not offer any significant reservations as to the means of using force in an unrestrained way. ${ }^{2}$ In both scenarios, the original conversion of force to power, in the reestablishment of power by the oppressed, and the means of confrontation are clearly related to both force and violence. Before proceeding to the second part of the analysis, one important observation must be made concerning the dialectic between the Master and the Slave. As Elster observed (Elster, 1984: 205) the struggle of forces competing for power has an additional element to be taken into consideration, namely the existence of the third party: the spectators of the conflict. It is because of the public, Elster argues, that the sides of the conflict enter a different realm of relations. The victor's honor is not only recognized by the defeated, but also by the disengaged other, whose recognition is not marred by the defeat. Additionally, the Slave in this scenario is not only humiliated by the defeat in the eyes of the victor, but also humiliated by the fact, that the public sees him fail and beg for mercy. This transformation of the conflict, from a Hegelian dyad to a triad brings the issue much closer to the social problem of the relationship between power and force. Curiously, as I will present in the next section, this third element seems to have even greater significance in a re-interpretation of the Slave's attempt at reestablishing power, as presented by Albert Camus in 1956.

${ }^{2}$ Hannah Arendt was understandably appalled by this Sartrean conclusion, which she conflated with Frantz Fanon's analysis in The wretched of the Earth. Homi K. Bhabha (Bhabha, 2007) and Emma Kuby (Kuby, 2015) pointed our however, that Sartre's analysis of Fanon, which clearly must have influenced Arendt's opinion, openly distorts the view that Fanon himself presented in his last book. A book by Kamel Daoud (Daoud, 2014) presents, on literary grounds, a vision, how such redemptive violence, performed by victimized colonial subject killing his former colonial Master leads nowhere near the restoration of individual dignity and social justice. 


\section{PART 2: POWER OF THE WEAK: DOMINATION WITHOUT FORCE}

The imagery of the relationship between power and force is very appealing. Force has to be used to dominate and then to instill power. But power, as has been already emphasized by Arendt (Arendt, 1970), does not have to originate from force. In fact, the entirety of Arendt's essay aims to establish a vision of power, that has no contact whatsoever with violence, and which does not need an excess of force to bring social order.

It seems evident to me, that the notions of power, force and violence are historically loaded and determined by the conceptual framework of current research. A simple example would be that before Johan Galtung (Galtung, 1969), Pierre Bourdieu (Bourdieu, 1992) and Michel Foucault (Foucault, 1983), greater stress was laid on the physical aspect of force and violence in the social sphere. With the development of research on symbolic and structural violence, a serious reorientation and extension of the field of study has occurred. Additionally, a purely analytical evaluation of bespoke notions may offer interesting results, but these will unavoidably be less helpful if we do not understand the dynamics of changes and cultural and historical contexts behind them. In addition, the contemporary imagery of the notions of force and violence leading to domination almost immediately bring back the echoes of European history and the role of Nazism in making us appalled by the consequences of power, founded on violence. An unfortunate conversion has occurred, as observed by Slavoj Žižek (Žižek, 2010). The modern liberal's reaction to violence (one inherited because of the ease with which Nazism dominated democracy in 1930's) is an almost intuitive revulsion against the phenomenon in the political realm. This, according to Žižek, is unfortunate, as almost all the engaged anti-violence humanists, who are obsessed with safeguarding their world from visible violence, as objectified by the figure of the Nazi, become blind to the systemic violence continuously depriving people of their dignity, rights and liberties in the apparently violent free democracies. In truth, Zižek's recent argument is not new, and seems to be a contemporary rephrasing of Maurice Merleau-Ponty's observations regarding humanism, who cautioned against condemning visible, revolutionary violence in the USRR, while not taking any measures against violence, which was occurring within western democracies (Merleau-Ponty, 2017). In this historical context, Žižek is another diagnostician, who warns us not to focus solely on the threat of a rapid, incurable cancer and its frightening symptoms, when we can die, peacefully and silently at night because of years of our unhealthy, capitalist diet. However, in order to be aware of the dangers from all sides, one does not need a blanket condemnation of all possible threats.

In the following part of this article, I would like to focus on the dangers of overlooking a seemingly forceless and violence-free strategy of power and 
domination that seems to be in line with the warning voiced by Žižek. ${ }^{3} \mathrm{Cu}-$ riously, it derives, as far as I'm concerned, from yet another, perceptive reinterpretation of the bespoken Master-Slave dialectic. I stumbled upon it, while re-reading The fall, and it can be summarized in a single remark by the book's protagonist, Jean-Baptiste Clamence: "What does it matter, after all, if by humiliating one's mind, one succeeds in dominating everyone?" (Camus, 1991: 55). Camus' novel contains an interesting literary vision of the considered relationship between power and force. It is interesting because it can be seen as an attempt at deconstructing the direct relationship between political power and the force used as a means to achieve it. Camus, like Arendt, argues that not all power comes from force. However, contrary to Arendt, Camus is skeptical about the nature of power in general and seriously considers the possibility that it corrupts the wielder, regardless of the means by which power has been taken. His story of Clamence can in fact be understood as a defense of a thesis that the most dangerous kind of political power may develop from restraints in using violence and force.

My proposition here will be to follow this old thesis from Camus' novel and, consequently, to show how relevant this vision is nowadays in a context, which is completely distant from the context of Camus's postwar warnings. First, I will focus on the issue of the "soft" strategy of reaching power without resorting to force and excessive violence in order to achieve the same status as the Master as found in the Master-Slave dialectic. In the following section, I will point out how this Camusian theory of deceitful strategy for domination works perfectly nowadays when considering selected examples from the contemporary, political sphere. In conclusion, I will be abstemious: my goal is to diagnose and bind the existentialist judgement with the contemporary situation, and suggest that thinking outside the force - power relationship may be continuously fruitful and an important part of reflecting on the nature of political power.

Camus's novel, clearly inspired by Kojève, offers a literary vision of how and why people become attracted to the idea of power. Curiously, the origin of Clamence's attraction towards power and domination is hidden in a seemingly banal story. Camus ironically replaces the quasi-mythical status of the struggle for power, with a mundane description of a street brawl: ${ }^{4}$ two drivers argue, one is beaten up and humiliated by the other, while observed by a crowd of passers-by. A situation, which could be observed any day on a busy street -

${ }^{3}$ That Žižek is a good diagnostician, does not mean that he is also in possession of any convincing solutions to the problem, as Simon Critchley (Critchley, 2009) noted in his reply to the Slovenian philosopher, regarding political violence.

${ }^{4}$ A sound evidence, that this part of Camus's novel is highly important: Camus made multiple changes in the section on this issue. After studying all available manuscripts, I can say that it is one of the most re-worked and re-edited parts of the novel. 
hardly a foundation for the social structure of society. The person humiliated, Clamence, narrates on the aftermath of being beaten publicly:

I could hear the "poor dope" which, in spite of everything, struck me as justified. In short, I had collapsed in public. As a result of a series of circumstances, to be sure, but there are always circumstances. As an afterthought I clearly saw what I should have done. I saw myself felling d'Artagnan with a good hook to the jaw, getting back into my car, pursuing the monkey who had struck me, overtaking him, jamming his machine against the curb, taking him aside, and giving him the licking he had fully deserved. With a few variants, I ran off this little film a hundred times in my imagination. But it was too late, and for several days I chewed a bitter resentment (Camus, 1991: 52).

The humiliated character from The fall confesses that he repeatedly imagined a reversal of the experienced abasement. Clamence creates an escape mechanism to cope with the negative effects of having been dominated and forced to accept someone else's will, by imagining revenge to an obsessive level (Camus, 1991: 55). It is also important to observe here the complete silence around the psychology of the victor of the street brawl. The one who possesses this power and control over others, the one who dominates, will hardly likely need a repeated analysis of the entire situation. Possibly, no alternative scenarios are drawn in his head, as he does not really have to think of the reverse situation: of having lost the fight. Perhaps, having woken up the next day, this person would hardly have the need to reflect on the issue. While for Clamance, on the contrary, this would be the first thing to obsess over for many hours. Camus argues that, in terms of power relations, having been forced to submit, and being humiliated and further reduced to insignificance, generates a very dangerous kind of reflection upon the situation, which has serious moral, social and political consequences. The will to become powerful becomes an Ersatz for the unrealized desire for recognition. Humiliation becomes the spiritus movens for domination. The basic assumption behind this vision of Master-Slave dialectic, clearly inspired by both Nietzschean analysis of resentment and Kojève's interpretation of Hegel, is that, on the one hand, those who are defeated, humiliated and deprived of power become overly active in the intellectual sphere, so as to compensate for the loss of dignity through the production of alternative scenarios in the ideational sphere. On the other hand, the victorious party in power does not have to be overly self-reflective. Once in power, fulfilled and recognized, the agent seemingly reaches an intellectual impasse. The question, however, remains: whose perspective is this?

Camus intentionally chooses a narrative, in which only Clamence has the power to speak his mind, although he is completely sure, he is at the same time rejected from society, excluded and humiliated on moral, social and political grounds. Thus, the answer seems to be obvious: the idea that people in power reach an intellectual impasse is clearly the perspective of the humiliated. The 
idea that those forced to submit must think, reflect and reconsider is accompanied by the completely unjustified assumption, that the other, dominating side does not have to spend too much time on intellectual activity. The genesis of this assumption is related to the need for self-confirmation of the subordinated party, as well as the need for depreciating the dominating agent or agency. However, the belief in the intellectual superiority of the dominated is just a compensation mechanism, not a fact, because the agent does not actually possess the knowledge as to the state of mind of the dominant agent. And this aspect can be clearly seen in The fall, where the person, who humiliated Clamence, is anonymous.

There is a strong contrast between the enormous quantity of information we have about the humiliated agent, and the inexistence of information we have with regards to the person, who humiliated Clamence. In effect of the intellectual activity of the humiliated person, an imaginary agent replaces the one, who is responsible for the situation. And in this re-reading of the Master-Slave dialectic, we may risk stating, that Kojève's argument, "Mastery is an existential impasse" (Kojève, 1980: 46) is not a fact: it is a belief, shared by the humiliated. The disturbing and alarming element of such vision is not only the fact that the power-wielding agent becomes illusory, but also that the perception of the one in power becomes static. The assumption that if one of the sides is very active and dynamic, then the other side must be passive is untenable. It is simply a coping mechanism of the humiliated mind to assume that he is the only one interested in progress, development and overcoming his own existential situation. In social reality, the person subordinated, who lives in a hierarchical society, as Galtung and Foucault have stressed, must confront many structural and symbolical obstacles, which limit his or her possibility to develop. On the side of the power-wielding agents, these obstacles simply do not exist, but the question at hand does not really relate to the individual sphere. If we consider Clamence's situation as a metaphor of an intellectual circle or political party striving for power and popularity among voters, then their main driving force is vengeance; compensation for humiliation that was isolated from the experience and maintained within the intellectual sphere. Clamence, as a potential leader of such a movement correctly assumes that it is very easy to create a political vision for the humiliated other: the promise of abolition of the imaginary, static Master (deprived in the reflective process of the intellectual abilities and possibilities for progress, change, development) and with him or her, the abolition of the status of Slavery. Consequently, to maintain popularity, threatening the other victims of social exclusion that this imaginary Master can take power back into his or her hands again. To be honest, there is nothing new in such strategy. This has been written many, many times before. Yet, the contemporary, populist movements, founded on a mechanism like the one Camus depicted in The fall, continue to exist and gain support. It would be interesting 
to know, why then does the culture that has already given us Origins of totalitarism and Anti-Semite and the Jew still have to struggle with the humiliated parties, who are thinking and rethinking their strategies for vengeance? There are, obviously, hundreds of great answers, contemporary analysis, political and sociological publications and social manifestations that try to answer this question in many convincing ways. My aim here will be much humbler: I want to focus on the relationship between becoming publicly humiliated and entering the sphere, where the will to power begins with compliance to force, violence and vengeance. In the social world, we are not like our own books, opposing the dangerous consequences of populist, political enterprises. In Camus' novel, Clamence confesses:

If I had been the friend of truth and reason I claimed to be, what would that episode have mattered to me? It was already forgotten by those who had witnessed it. I'd have barely accused myself of having got angry over nothing and, having got angry, of not having managed to face up to the consequences of my anger, for want of presence of mind. Instead of that, I was eager to get my revenge, to strike and conquer (Camus, 1991: 55).

I see this statement as encapsulating a very important element of the problem. There is a tension between thinking of oneself as a friend of truth and reason and the reaction to being publicly humiliated. Friends of truth and reason tend to be very aggressive when dealing with friends of a different view of truth and reason. Once humiliated, they fight back, and each reader, who is aware of the discussion between Camus, Jeanson and Sartre in 1952 will hardly be surprised by such a statement (Aronson, 2004). Once confronted with alternative ways of thinking, friends of truth and reason want to humiliate other friends of truth and reason, and dream of vengeful ways of dealing with those, who have rejected their thesis, books and papers. In short, the tension is that quite a number of friends of truth and reason are quite hostile to truth and reason, once their alleged possession of truth and reason becomes publicly questioned. I find it quite hard to understand, in this context, why so many intellectuals are lamenting the reactions of the socially humiliated, who join radical and populist movements. Being aligned to liberal, tolerant and progressive parties many of us could do a much better job, once we start rethinking the whole issue after a personal confession, and recognize the dangers in our own reactions to the bespoken, falsely perceived, possessive account of truth and reason. If we, the philosophers, political theorists and sociologists are not always able to control our anger and maintain serenity of mind, why are we surprised and concerned about populist movements reacting in a similar way? Worse still, it may be that we, the friends of truth and reason, are losing the contemporary battle of ideas, because the dreaded self-proclaimed leaders of the humiliated are further ahead when it comes to anger management. 


\section{PART 3: TOWARDS CONTEMPORARY MANIFESTATIONS OF CLAMENCE'S STRATEGY}

The best way to gather attention is to proclaim one's state of isolation from the elites. "We are with the weak, the excluded, the oppressed". "We solidarize with the minorities". "We sympathize with those, whose jobs were given to the immigrants". Because forcefulness and being violent gathers negative attention, so becoming the spokesman of victims as a means of gaining power seems much more effective. The rhetoric of contemporary populism proves this scenario to be effective. Instead of saying only "We are against immigrants entering the country", Polish right-wing politicians warned of the dangers of accepting people into their country, framed as care for their citizens. The reasons enumerated were appalling. Immigrants could not enter due to the risk of infections, which would be introduced by them (Dziennik.pl, 2015). Some radical right-wing organizations raised concern as to the safety of Polish women, which would be threatened by immigrants (Kościańska, 2015). The German political party, AfD (Alternative für Deutschland) openly confessed, that their goal is to protect the LGBT population in Germany against the anti-Semitic and homophobic attitudes of refugees who seek asylum in their land (Lewicki \& Shooman, 2019). The patriarchs of the Catholic Church in Poland instead of dealing with the growing evidence of sexual harassment by priests, launched a campaign, in which they voiced concern about the rise of "LGBT ideology", which they claim threatens and harms Polish children (Makarewicz, 2019) - apparently this is more serious than the reported cases of sexual abuse perpetrated by priests. Frequently, in contemporary, populist discourse, recourse to violence has been removed or silenced in the political debate. Forceful solutions are toned down, or even condemned, to validate an attitude of concern for the lot of the weak, the excluded and the oppressed. In each of the cases, a process of self-humiliation may be observed. Homophobic politicians present themselves as being concerned for the fate of homosexuals. Islamophobic activists dress themselves as feminists, concerned about the safety of women in a country, where almost all domestic violence is perpetrated by catholic males. "What does it matter, after all, if by humiliating one's mind, one succeeds in dominating everyone?"

The greatest success of Clamence from The fall, at least to me, is that he is likeable. I have observed in theatre that people were genuinely amused by his statements. Openly self-critical, witty and ironic, he gathers the attention of the reader of the novel and of the audience of the staged version of Camus's work. In the play, Rbinocéros, by Eugene Ionesco, a transformation of a person by a dangerous and violent political ideology was metaphorized by the transformation of a person into a rhinoceros: a violent, self-confident and forceful creature. However, following Camus's lesson, we seem to be in need of a new 
play nowadays. A play, in which everyone, who is willing to dedicate his political career to the fight against democracy, for the benefit of power, rather than for the benefit of people, turns into a panda. Cuddly, non-violent and trustworthy, allegedly caring for the poor and the weak. Winning elections repeatedly, against all odds and despite every poll. After all, who wouldn't vote for a panda? But these seemingly non-hostile creatures are actually very similar to Clamance in the political realm. They publicly condemn violence and praise humanity, while simultaneously, secretly writing odes to slavery and guillotines. Beneath the mask of the trustworthy, self-criticizing Clamence, was a sexual predator. He lamented on the fate of a woman from a Parisian bridge (or rather on his own failure to act at the right time), but he did not lament on the fate of a woman, who he sexually abused and humiliated (Camus, 1991: 64-65). He speaks of the brotherhood of men, but in his weakest and darkest moment, confesses to having stolen water from a dying comrade in a German camp (Camus, 1991: 126-127). Perhaps modern politicians aren't as dangerous in their struggle to power, when they openly praise force, violence and efficacy. Maybe some of them are much more dangerous, when they don't. The question then is not whether to study the relationship between their attitude to forceful solutions of political impasses. The question, and it is a much more difficult one, is to know how to distinguish those, who genuinely care for the weak, from those, who instrumentally use the support of those who are excluded and oppressed to dominate others?

This does not mean, that everything that Camus had envisioned years ago should be applied uncritically to our current, political situation. To gain more sympathy from the listener, Clamence confessed that his narrative is a mixture of truth and lies, with the aim of leaving the listener unable to distinguish between them. Furthermore, in this honest confession he is completely alien to most populist parties. In the post-truth era, many politicians don't care about such confessions anymore, because of their shared belief that opinions have no direct relation to the truth whatsoever. Thus, no one can actually confess; the contemporary Masters of the narratives are, at the same time, their Slaves. The act of confession requires one, at least temporarily, to remove one's mask. Consequently, the greatest victory of contemporary populist discourse is the apprehension of such a confessional act. That is to say that today a politician cannot honestly say "I lied", because, in order to lie one must have a conception of truth and a possibility to share with the listener - like Clamence the true nature of the situation behind all the smoke and mirrors. With the declared disappearance of truth, at least in the political debate of the populist era (McIntyre, 2018: 213-236), this strategy becomes much more problematic. In one of the re-workings of the ending of The fall, Clamence is arrested by a Belgian policeman, who actually listens to his story so as to gain access to the truth, behind the confession, and arrest Clamence for the theft of the 
painting. The just judges (Camus, 2008: 765, 770) in the final, published version, Clamence triumphs over his listener and reverses the situation, by making him - and us, the readers - start thinking about likeness, not difference. He is doing his best to disable the ability to be judged, because he firmly believes that power and judgement are two sides of the same coin.

Clamence believed that he will gain access to power, without resorting to force, without open violence, by the mere fact of making others believe, that they are like him. Once the listener falls prey to his confession, he or she starts thinking about his or her own weaknesses and becomes less resistant to the power of Clamence. Our situation, when confronting contemporary populist movements may be worse. Clamence at least had the dignity to hide the truth between lies: his genuine compassion towards the other, alongside his inability to start a rebellion because of his companion's suffering, accompanied by the knowledge, that he could have done something to change history. He had a vision of a world of duties and, to a certain extent, a belief in the possibility of introducing them to the realm of facts. Through constant repetition of his failures, accompanied by ineffective words of self-assurance, he couldn't eliminate this "flaw". His power over others had thus a severe limit: the recognition of others, that they actually possess the power to say "I am not like you". Once this happens - and this is not presented at all by Camus in novel - the whole "soft" surround of the confessing agent disappears. But it is not easy to interrupt the pleasant, soporific monologue. It requires strength, confidence and integrity. It requires consequence and an acceptance of risk. Overcoming of the fear, that this intervention will end in violence and yet another struggle of forces for yet another domination.

\section{CONCLUSION}

Currently, it is so much easier to "feed" genuine protesters and rebels with Facebook likes, rather than joining them on the streets: to admire Greta Thunberg's actions, discreetly, from the comfortable university chair; to devote time and energy to signing countless internet petitions, which must have originated from the French word "petite" in the realm of efficacy. In these post-truth times, we may have perhaps created a new kind of social phenomenon: a post-rebellion, which is an act of revolt that is usually limited to posting something on the internet.

When the populists gain power, the consolation that they will reach their political impasse is just wishful thinking of those, who are against them. The only way to make them reach impasse is to confront them, genuinely. Expose their misconceptions effortlessly. Explain one's causes without embarrassment. Arendt observed that violence substitutes power, to compensate for the 
deterioration of it (Arendt, 1970: 52-53). However, power can also be possessed, maintained and deteriorated by authoritarian regimes without resort to violence (at least not explicit violence), with the advantage for the rulers, of not having to suffer the negative consequences of public exposition of their violent means of control. Curiously, such a solution seems, in very general terms, to be accepted nowadays by those, who disengage from conflict with opposing populist political parties. Perhaps the strategy of liberals and democrats was wrong: in fear of possibility of force being used again, in fear of violence substituting democratic liberal means of conflict resolution, we have overlooked the possibility of power being taken over by radicals, only because they didn't seem openly violent and didn't resort to criminal activities. Satisfied by the apparent control of the behavior of political opponents, too many contemporary politicians have learned to ignore signs of latent violence, the unresolved hatred, ${ }^{5}$ the desire for control and domination of the humiliated, silenced and excluded.

Consequently, in doing nothing today against those, who ridicule ideas of democracy, liberty and justice, who allegedly support the voice of the humiliated, we are in effect guilty of becoming accomplices of those, whom we should oppose, because doing nothing is sufficient enough for them to take over.

\section{BIBLIOGRAPHY}

Arendt, H. (1970). On violence. Orlando: HMH Books.

Aronson, R. (2004). Camus and Sartre: The story of a friendship and the quarrel that ended it. Chicago: University of Chicago Press.

Bhabha, H.K. (2007). Foreword: Framing Fanon (pp. vii-xlii). In: F. Fanon. The wretched of the Earth. New York: Grove Atlantic.

Bufacchi, V. (2007). Violence and social justice. London: Palgrave Macmillan UK.

${ }^{5}$ The correlation between the rise of populism and latent social violence, especially hate crimes has been researched recently in Germany (Rees et al., 2019). As I have been working for several years in an organization reporting hate crime in Poland, I have personally witnessed at least two serious aspects of this phenomenon. The first, recently researched more thoroughly (Ipsos Poland, 2018) is underreporting of hate crimes by their victims, leading to biased view of the situation in police statistics. Majority of victims of hate crimes, that I have contacted never called the police to report the crime, which is supported by the research, in which only $5 \%$ surveyed victims reported the incident. The second is the tendency of law enforcement members to disregard political, racial or homophobic aspects of crimes in their official statistics. Cases of politically, religiously or racially motivated hate crime incidents I have reported to Never Again "Brown Book" - a documentation of hate crimes, racist and xenophobic incidents - have not been classified as such by the law enforcement or prosecutors. In some cases (Ipsos Poland, 2018: 52-52) victims reported the policemen discouraging them from reporting the crime. In effect we may observe, that on the one hand, populist parties influence violent behavior of citizens, provoking distrust towards minorities, refugees and political opponents. On the other hand, once in power, these parties attempt at obscuring the effects of such political influence by downplaying the role and scale of social violence in the society. 
Bourdieu, P. (1992). Symbolic violence (pp. 140-174). In: L. Wacquant. An invitation to reflective sociology. Chicago: University of Chicago Press.

Camus, A. (1991). The fall. London: Vintage Books.

Camus, A. (2008). Euvres complètes III. Paris: Gallimard.

Coady, T. (2007). Morality and political violence. Cambridge: Cambridge University Press.

Critchley, S. (2009). Violent thoughts about Slavoj Zižek. Naked Punch. Retrieved from: http://www.nakedpunch.com/articles/39 (06.03.2020).

Daoud, K. (2014). Meursault, contre-enquête. Arles: Actes Sud Littérature.

Dewey, J. (1916). Force, violence and law. The New Republic. Retrieved from: https://www. unz.com/print/NewRepublic-1916jan22-00295/ (06.03.2020).

Dziennik.pl. (2015). Imigranci zarażą Polaków cholerą? Kaczyński przywołuje dokument resortu zdrowia. Retrieved from: https://wiadomosci.dziennik.pl/polityka/ artykuly/503000,jaroslaw-kaczynski-o-chorobach-uchodzcow-i-rozporzadzeniu-ministra-zdrowia.html (15.02.2020).

Elster, J. (1984). Ulysses and the Sirens: Studies in rationality and irrationality. Cambridge: Cambridge University Press.

Foucault, M. (1983). The dubject and power (pp. 208-226). In: M. Foucault. Beyond structuralism and bermeneutics. (H. Dreyfus \& P. Rabinow, Eds.). Chicago: The University of Chicago Press.

Fanon, F. (2007). The wretched of the Earth. New York: Grove Atlantic.

Galtung, J. (1969). Violence, peace and peace research. Journal of Peace Research, 3, 167-191.

Ionesco, E. (2002). Rbinocéros. Paris: Gallimard.

Ipsos Poland. (2018). Survey on the nature and scale of unreported hate crimes against members of selected communities in Poland. Warsaw: Office for Democratic Institutions and Human Rights. Rertieved from: https://www.osce.org/odihr/412445 (18.04.2020).

Kojève, A. (1980). Introduction to the reading of Hegel. Ithaca: Cornell University Press.

Kościańska, A. (2015). Dla polskich mężczyzn perspektywa obrony kobiet przed uchodźcami to symboliczna wyprawa krzyżowa. Interview with Agnieszka Kościańska by Lidia Ostałowska, 18 November 2015. Retrieved from: https://wyborcza.pl/duzyformat/1,127290,19206835, dla-polskich-mezczyzn-perspektywa-obrony-kobiet-przed-uchodzcami.html (06.03.2020).

Kuby, E. (2015). “Our actions never cease to haunt us”: Frantz Fanon, Jean-Paul Sartre, and the violence of the Algerian War. Historical Reflections, 41(3), 59-78. https://doi.org/10.3167/ hrrh.2015.410305.

Lewicki, A. \& Shooman, Y. (2019). Building a new nation: Anti-Muslim racism in post-unification Germany. Journal of Contemporary European Studies, 28(1), 30-43. https:// doi.org/10.1080/14782804.2019.1647515.

Makarewicz, B. (2019). Abp Jędraszewski znów o LGBT: Dla rodziców nie może być większej tragedii. Retrieved from: https://wiadomosci.radiozet.pl/Polska/Polityka/ Marek-Jedraszewski-znow-o-LGBT-Dla-rodzicow-nie-moze-byc-wiekszej-tragedii (06.03.2020).

McIntyre, L. (2018). Post-truth. Cambridge: MIT Press.

Merleau-Ponty, M. (2017). Humanism and terror: The communist problem. London: Taylor $\&$ Francis.

Rees, J.H., Rees, Y.P.M., Hellman, J.H., \& Zick, A. (2019). Climate of hate: Similar correlates of far right electoral support and right-wing hate crimes in Germany. Frontiers in Psychology, 18 October. https://doi.org/10.3389/fpsyg.2019.02328.

Sartre, J.-P. (1961). Préface (pp. 17-36). In: F. Fanon. Les damnés de la terre. Paris: Maspéro.

Stallybrass, P. \& White, A. (1986). The politics and poetics of transgression. Ithaca: Cornell University Press.

Žižek, S. (2010). Violence. London: Profile. 
